Corrêa, H.L.'; Venturini, M. A. F.A.2. Venceslau, A. ${ }^{3}$; León Román, M. A. ${ }^{4}$; Gioso, M.A. ${ }^{5}$

\section{0 - Restauração biológica através da colagem de fragmento dentário alógeno. Uma nova alternativa na reconstrução de dentes fraturados}

1- Mestre em Cirurgia da Faculdade de Medicina Veterinária e Zootecnia da Universidade de Săo Paulo, São Paulo-SP

2- Médico Veterinário autônomo - Odontovet, São Paulo-SP

3- Médico Veterinário autônomo - Odontovet, Săo Paulo-SP

4- Médico Veterinário autônomo - Odontovet, São Paulo-SP

5- Departamento de Cirurgia da Faculdade de Medicina Veterinária e Zootecnia da Universidade de São Paulo, São Paulo-SP

Diversas técnicas têm sido usadas para restaurar dentes fraturados. Desde 1964, vários autores têm descrito a colagem de fragmentos dentários como técnica alternativa para restaurar dentes anteriores fraturados em pacientes humanos. As vantagens citadas são: preservação das estruturas dentais, economia de tempo quando comparado ao tempo necessário para fazer uma restauração grande em resina composta fotopolimerizável, resultado estético imediato, o fragmento dental apresenta propriedades bio-mecânicas ideais, dentre outras. Nào foram encontrados na literatura relatos da técnica em cães. Este trabalho apresenta cinco casos de dentes caninos fraturados de càes que foram restaurados pela técnica de colagem de fragmento dentário alógeno obtidos de um banco de dentes. Os pacientes foram selecionados quando apresentavam pelo menos metade da coroa fraturada. O procedimento foi realizado em três etapas. Na primeira, sob anestesia geral, foi realizada profilaxia dental e tratamento de canal convencional, seguida de moldagem para obtenção de modelo de estudo em gesso e moldagem do conduto radicular para confecção de pino intra-radicular fundido em niquel-cromo. O paciente foi mandado para casa com uma restauração provisória. A segunda etapa foi realizada em laboratório, sendo feita a adaptação do fragmento dentário ao modelo de gesso com auxilio do pino fundido. Na terceira, o paciente foi reanestesiado e o pino intra-radicular e fragmento dentário foram colados ao remanescente dental fraturado com auxilio de cimento resinoso dual. Pequenas irregularidades na linha de colagem foram restauradas com resina composta fotopolimerizável. A oclusão foi checada e havendo qualquer contato prematuro este foi removido através de odontoplastia. Um acompanhamento mensal por telefone foi feito. O proprietário respondia se o dente restaurado estava intacto ou não. Este acompanhamento até o presente momento revela: No caso 1, proprietário referiu perda do fragmento colado após sete meses. Optou-se por colagem de um novo fragmento que veio a cair quatro meses após. No caso 2 , foi informado perda do fragmento colado seis meses após. No caso 3 , após nove meses de acompanhamento, o proprietário refere que o dente está intacto. No caso 4, houve perda do fragmento 19 dias após a colagem e no caso 5 , sete dias após a colagem, mas além do fragmento perdeu o pino e também houve fratura do remanescente, sendo optado apenas por restauração com resina fotopolimerizável. Os resultados desta pesquisa clínica revelam que a colagem de fragmentos dentários é viável em cães, no entanto, a alta incidência de falha (perda do fragmento) pode estar relacionada à variáveis, tais como técnica operatória inadequada ou maus hábitos dos pacientes (p. ex. roer objetos duros, etc). Tais observações apontam para a necessidade de pesquisas para aprimorar a técnica de colagem em càes, proporcionando a adaptaçào de conceitos humanos conhecidos. Até que isto ocorra, parece plausível propor que este tipo de restauraçào seja indicada em pacientes que sofreram fratura dental acidentalmente e não naquelas ocasionadas por maus hábitos. 